SECTION 18. Culturology.

Shamarova Svetlana Iliinichna

Associate Professor, Ph. D. in Philology

The Ufa state university of economy and service, Russia

shamarova@list.ru

\title{
REGARDING THE ORIGIN OF OLD ENGLISH VOCABULARY AND MANUSCRIPTS
}

\begin{abstract}
The article presents different versions of the origin of Old English vocabulary: Christian impact, Asian (Persian- the languages of Pehlvi and Zend) as well as Latin. Old English vocabulary is typical of mixed nature (religious and nonreligious) with predominance of the religious character. Old English manuscripts (including sacred ones) originate from mythology and folklore.
\end{abstract}

Key words: Christian impact, Persian and Latin influence, predominance of religious nature, sacred manuscripts, mythology and folklore.

\section{О ПРОИСХОЖДЕНИИ ДРЕВНЕАНГЛИЙСКОЙ ЛЕКСИКИ И ЛИТЕРАТУРЫ}

Аннотация: В статье представлень различные источники происхождения древнеанглийской лексики: христианское воздействие, азиатское (персидское-языки Пехлви и Зенд), а также латинское влияние. Древнеанглийская лексика характеризуется смешанным составом (религиозным и нерелигиозным) $c$ преобладанием религиозного. Древнеанглийская литература ( в том числе сакральная) восходит к мифологии и фольклору.

Ключевые слова: Христианское воздействие, персидское и латинское влияние, преобладание религиозного состава лексики, сакральные тексты, мифология и фольклор.

Bce более популярными за последнее десятилетие становятся термины религиозный язык, лексика и «религиозная филология» (по определению А.Н. Хоца) [2, с. 483] или ее эквивалент теолингвистика (термин Ж.-П. ван Ноппэна), идентичный лингвотеологии (термин автора - С.Ш.). Переход древних германцев из языческой культуры в христианство значительно повлиял на их язык вплоть до наших дней. Западный лингвист Пит Скалли изучил христианскую терминологию, заимствованную готами и англосаксами и какое действие их выбор словарного состава оказал на древневерхненемецкий и древнесаксонский языки. Сравнивая готские евангелия епископа Вульфилы с поздними древнеанглийскими переводами, различия между ними очевидны. Один пропуск наблюдается в слове, используемом вместо Lord «Господь» при обращении к Богу или Христу. Вульфила употребляет frauja «господин, госпожа», в то время как в древнеанглийском это слово dryhten. Древнесаксонское родственное слово drohtin используется наряду с Heliand «Целитель, Спаситель». Причины использования готского слова frauja вместо гот. *drauhtins, возможно, не имели религиозной коннотации. Эквиваленты обоих терминов широко употреблялись в Германии при описании языческих божеств, но последнее слово, по-видимому, было тесно связано с идеей военного лидера, вождя. Более того, кроме попытки запутанного лексикона, Вульфила также использует греческие заимствования (калькирование). Так, например, англосаксы перевели лат. evangelium (от греч. «благая весть») как godspell, a готы просто заимствовали из греческого слово aiwaggelyo. Св. Бонифаций, фризский миссионер из Рима, обратил в христианство многих германцев. Много английской терминологии носило отпечаток кельтской церкви (из Нортумбрии). В то время как 
кельтские слова-кальки в древнеанглийском языке были ограничены, привычка превращения языческих понятий в христианские продолжалась. Настоящим символом являлась неотъемлемая часть миссии Бонифация, который сам разрубил Irminsul (наподобие Мирового древа Yggdrasill), огромное дерево, которому поклонялись саксы и фризы, чтобы доказать, что христианский бог был могущественнее язычников, за что он был замучен. До сих пор существует один христианизированный языческий термин, который выжил в некоторых германских языках. То, что в голландском языке называют Pasen, в шведском Pask, в английском Easter, в немецком Ostern, восходит к и.-е. *ausro «рассвет» (от лат. aurora, литов. auszra, связанные с именем славянской богини рассвета Auska ). Интересно отметить, что пока это слово (древнеангл. Easter) процветало в древневерхненемецком как ostarun, оно не вошло в древнесаксонский вместо pascha, как и в готском paska, в конечном итоге, производное от древнееврейского Pesach. Однако англосаксы употребляли обе формы (например, в “Англосаксонской хронике” встречаются Easterdaeg и Pasche) [7, с.1-2]. Эти два слова - теонимы Easter "Пасха" и Lent "великий пост, весна" тесно связаны друг с другом так же, как и их концепты. Интересно отметить, что в современном английском языке главным значением Lent является “великий пост”, а второстепенное, разговорное значение - “весна”, хотя в историческом ракурсе было все наоборот. Эострэ (Эастрэ) - это языческая англосаксонская богиня Восхода солнща и Весны, Изобилия и Плодородия. Она является прагерманской богиней Рассвета. В ее честь названо направление восхода солниа Восток (английское однокоренное слово Еast). В древнескандинавской мифологии ее имя писалось Эостарэ. Еще одной древнескандинавской и саксонской богиней Весны была Остара. Eastre - древнее слово для обозначения весны. Еще одна история о происхождении теонима Еаster связана с Франкской церковью (франки - это германщы, которые поселились в Риме в V веке). Их празднование воскресения Христа связано со словом alba "бельй" (ивет мантий, которые носили священнослужители во время праздника Воскресения. Слово alba также означало "восход солния". Поэтому, когда название праздника было переведено на немеикий язык, то, вероятно, по ошибке было выбрано слово оstern со значением "восход солнцуа". Согласно одной из гипотез теоним Easter происходит от немецкого слова Ostern [6, c.1-2]. Важным примером религиозной лексики, который вошел и в древневерхненем. (heilac druhtin «святой господин» - от протогерманского *hailagaz) и в древнесаксонский через древнеанглийское влияние, является heilag/helag «святой» (древнеангл. halig), что обозначало «подарок богов для их племенных почитателей» для защиты в военных действиях. Таким образом, существует объяснение в принятии военных терминов в христианской лексике во времена Бонифация для избежания такого языка Вульфилой [7, с.3]. Вслед за праздником Пасха можно упомянуть праздник Рождество. Наблюдается весьма прозрачная этимология у древнеангл. теонима cristmas “рождество”, т.е. букв. “месса (богослужение) Христа”. Западный лингвист Шарон Тернер в своей статье выдвигает гипотезу об азиатском происхождении англосаксов. Птолемей вслед за Страбо и Плинием во II веке отмечают, что скифы, которые были потомками Сакаи (по имени саксонцы) восходят к сыновьям Сакаи, что свидетельствует о том, что англосаксы пришли из Азии в Европу и осели в Армении и в районах Каспийского моря. Предположительно между реками Аррас и Кур находится провинция Карабах (бывшая страна Сакассани и нынешняя территория России), возможно, когда-то была одной из стоянок англосаксонских предков. Ш.Тернер подчеркивает некоторое сходство слов персидского языка с саксонским (например, fader «отец», muder «мать», brader «брат», tuchter «дочь», band «группа» все еще используются в персидском языке). Это сходство является небольшим, т.к. саксы не произошли от персов (Сакаи были только родственным племенем, а не детьми персов). По ее мнению, их языки могли быть диалектами языковой семьи и поэтому имели 
много общих терминов (например, между древними франко- теотиским и саксонским языками и, соответственно, в англосаксонском и современном персидском). Она нашла 162 персидских слова, которые имеют родство с англосаксонскими терминами одинакового значения. Ш.Тернер упоминает о двух других, более древних языках, чем современный персидский, которые преобладали в той стране 2000 лет тому назад (это Пехлви и Зенд). Таким образом, из 162 слов 57 - из зендского языка, 43 - из языка пехлви имеют достаточное сходство с многими древнеанглийскими словами, что подтверждает древнее происхождение англосаксонских предков из этих районов древней Азии (географическое местоположение в районах Каспийского моря и Персии). Например, древнеангл. raed «дорога», персид. raeh «путь»; древнеангл. mare «больше», перс. mar «большой»; древнеангл. halig «святой», перс. halae «чистый»; древнеангл. lufu «любовь», перс. laheb «любовь»; древнеангл. beam «луч солнца», перс. bam «утро»; древнеангл. blessian «благословить», перс. balistan «благословить» и т.д. [9, с.1,3,4]. Любопытна гипотетическая фольклорная этимология английского слова $\sin$ «грех». Син (Sin) было именем вавилонского бога Луны и никакого прямого отношения к древнеангл. слову synn не имеет (ср. родственные слова: голланд. zonde, древнесакс. sundia, древневерхненем. suntea, древнесканд. synd, нем. Sunde). Слово восходит к и.-е. корням *es «быть» и является причастием настоящего времени «бытие», также лат. esse (sons, sont с значением «вина, виновный» в лат. яз., т.е. «обвинение доказано, это правда»). Греческое слово hamartia часто переводится как грех в Новом Завете, оно означает «пропустить мишень, цель; промахнуться» [8, с.1]. В связи с вышеизложенными фактами, необходимо подчеркнуть огромную роль в использовании общих и специальных методов герменевтики в толковании древних сакральных текстов и семантики древних слов в целом. В работе О.В. Миронова рассматриваются три основных метода: 1) «историко-логический анализ развития теологической герменевтики, предполагающей выявление оппозиции “синхроническое-диахроническое" и взаимосвязи этих аспектов экзегетики (например, явления переноса смыслов при полисемии); 2) семиотический анализ, развитый в трудах по семиотике, языкознанию и типологии культуры; 3) идейно-содержательный анализ теологической герменевтики, развивающийся в различных школах общей герменевтики и библеистики» [4, с.7]. По его мнению, сакральный текст отличается от других типов текстов (научного, художественного, сказки и др.) определенными признаками, в основе которых лежат специфические методы толкования сакральных текстов, не имеющих аналогов в светской герменевтике: прототипический, буквалистский и теологический анализ. Основными методами интерпретации библейских текстов являются методы историко-культурного, контекстуального и лексико-синтаксического анализа. Кроме того, выделяются вспомогательные экзегетические приемы, которые делятся на текстологические, синтаксические и риторические. Методы лексико-синтаксического, историко-культурного и контекстуального анализа текста и вспомогательные экзегетические приемы являются общими и для теологической, и для светской герменевтической практики, но в случае их применения для сакральных текстов они наполняются специфическим эсхатологическим, экклезиологическим или сотериологическим содержанием и приобретают теологическую функцию [там же, с.10, 18, 20]. В своей работе, посвященной анализу сакральных текстов, Г.В. Гриненко упоминает заявление Л. Леви-Брюля о дологическом мышлении первобытных людей. Это мистическое мышление, основанное на неклассической логике, отчетливо проявляется именно в сакральных текстах и различных религиозно-философских и мистических учениях, предлагающих интерпретации для этих текстов. По его мнению, не существует ни одного текста, который всеми людьми, всегда и везде признавался бы сакральным. Как особо важный выделяется признак «наличия магической силы», приписываемый 
большинству сакральных текстов, а также о значительной роли сакрального ритуала. Семантика сакральных текстов должна учитывать многозначность терминов, при этом одни значения могут относиться к обыденному миру, а другие - к сакральному [2, с.4$5,13,15]$. В своей работе Т.Г. Логутенкова отмечает, что «историко-типологическое исследование позволяет определить сдвиги в типологии как отдельного языка, так и всей группы. Анализ переводных текстов дидактических письменных памятников показывает использование двух различных способов перевода: буквального и перевода-интерпретации. В зависимости от типа перевода в текстах по-разному отражаются объективные процессы языкового развития и степень влияния латинского языка» [3, с.3, 10]. Т.Г. Логутенкова на материале древнеисландского, древнеанглийского и древневерхненемецкого языков рассматривает различия между собственно терминами и потенциальными терминами. В то время как первые показывают относительную самостоятельность, вторые непосредственно зависят от латинского образца. Ограничение сферы бытования средневекового термина влечет за собой возможность варьирования и формальной, и содержательной стороны термина. На более ранних стадиях развития науки научной деятельности был свойствен оттенок популяризаторства, дидактизма и просветительства, и формирование научной терминологии было связано с объяснением терминов. В случае заимствования чужой научной концепции и сложившейся терминологии термины в основном являются кальками, а не лексическими заимствованиями. По ее мнению, в средние века германские народы в процессе приобщения к христианской религии переживали смену дохристианских представлений о нравственности христианскими, что выражалось во взаимодействии дохристианских и христианских нравственных кодексов. В дохристианских представлениях германцев этическое как мыслительная категория слабо вычленяется из совокупности положительных и отрицательных оценок героев и их поступков. Цементирующими элементами в лексико-семантической группе с значением нравственно-этической оценки являются лексемы с обобщенным значением, как, например, «добро/хороший» и «зло/плохой», которые являются кальками латинских слов, обозначающих нравственные категории. Формирование литературного узуса в древних германских языках происходит в результате взаимодействия двух литературных традиций (германской и латинской). По характеристикам литературного узуса древнеанглийский язык занимает промежуточное положение между древневерхненемецким и древнеисландским, тяготея к древнеисландскому, т.е. с относительно устойчивым литературным узусом и относительной устойчивостью к иноязычному влиянию [там же, с.12-18,36,40-41]. Общеизвестно, что древнеанглийские письменные памятники сохранились не полностью, а фрагментарно (особенно поэзия). Кроме того, для древнеанглийской письменности характерно явление иллогизмов, т.е. отсутствие какой - либо логической связи между отдельными частями целого текста, что приводит к разрозненности текста и нарушению целостного его восприятия, т.е. к смысловой изоляции, что вызывает полиинтерпретацию многих концептов и слов и всего произведения в целом. Подобное явление значительно повлияло на формирование концептуально - семантического дуализма, синкретизма, контаминации, диффузности и широкозначности в древнеанглийской языковой системе, что, несомненно, обусловлено спецификой мышления средневекового человека. Древнеанглийская лексика характеризуется диффузно-смешанным составом - религиозно-нерелигиозным. Эти два главных языковых пласта находятся в амбивалентных отношениях с большим преобладанием религиозного, так как априори последний является основополагающим, образующим религиозный язык как метаязык, праязык любого национального литературного языка в силу культурно-исторических факторов (все древние письменные памятники в подавляющем большинстве имели религиозное содержание). В отношении древнеанглийской письменности, как и 
исландских саг можно употребить понятие «синкретическая правда», введенное М.И. Стеблиным-Каменским. Синкретическая правда представляет собой архаическую нерасчлененность художественной и исторической правды и предполагает конкретное описание событий так, как будто они действительно имели место. М.И. Стеблин Каменский говорит о неосознанности авторства, в то время как по мнению А.Я. Гуревича, в авторстве сочетаются индивидуальное и коллективные начала [цит. по: 1, с. 9]. Другими словами - древние литературные памятники (включая сакральные тексты) фактически являются фольклором и мифологией.

\section{ЛИТЕРАТУРА}

1. Барышников В.Ю. Представления о судьбе в средневековой Исландии как форм исторического сознания. Автореф. дис....канд. филол. наук. Иваново, 2007. - 23 с.

2. Бочаров С.Г. О религиозной филологии//Литературоведение как проблема.Труды Научного совета «Наука о литературе в контексте наук о культуре». М.: Наследие, 2001. С. 483-498

3. Гриненко Г.В. Сакральные тексты и сакральная коммуникация. Автореф. дис.... д-ра философ. наук. М., 2000. -37 с.

4. Логутенкова Т.Г. Историко-типологическое исследование германских литературных языков в донациональный период (на материале древнеанглийского, древневерхненемецкого и древнеисландского языков). Тверь: изд-во ТГУ, 1993. -170 с.

5. Миронов О.В. Развитие герменевтических практик в толковании сакрального текста. Автореф. дис. ... канд. философ. наук. Воронеж, 2002. - 21 с.

6. The origin of the word Easter.//URL: http://www.allabouthistory.org/origin-of-theword-easter-faq.htm. Дата обращения: 15.06.11 г.

7. Skully P. Essay "In what ways did the Gothic and Anglo-Saxon missions influence the Christian vocabulary adopted in Germany?" //URL: http://www.angelfire.com/oh/rickyvilla81/germanicessay.html. Дата обращения: 15.06.2011 $\Gamma$.

8. Synn name. What is the origin and meaning of the word sin? //URL: http://answers.yahoo.com/question/index?qid=20081006132647AAhrszt. Дата обращения: 5.07.2011 г.

9. Turner $\mathrm{S}$. On the Asiatic origin of the Anglo-saxons. //URL: http://www.abcog.org./turner.htm. Дата обращения: 10.07.2011 г. 